\title{
Persepsi Manfaat, Persepsi Kemudahan, Norma Subjektif, Kualitas Informasi dan Minat Penggunaan: Studi pada Pengguna E-commerce
}

\author{
I Made Fery Aditya ${ }^{1}$ \\ Fakultas Ekonomi dan Bisnis \\ Universitas Udayana, Indonesia
}

\author{
I Made Pande Dwiana Putra ${ }^{2}$ \\ Fakultas Ekonomi dan Bisnis \\ Universitas Udayana, Indonesia
}

\begin{abstract}
Surel: adityafery05@gmail.com
\section{ABSTRAK}

E-commerce merupakan konsep umum dalam proses jual beli produk atau jasa melalui jaringan internet. Teori Technology Acceptance Model menjelaskan bahwa sejumlah faktor memengaruhi perilaku pengguna sistem informasi. Tujuan dari penelitian ini adalah untuk mendapatkan bukti empiris pengaruh persepsi manfaat, persepsi kemudahan, norma subjektif, dan kualitas informsai terhadap minat menggunakan $e$ commerce. Penelitian ini dilakukan pada seluruh mahasiswa aktif jurusan Akuntansi angkatan 2016 di Fakultas Ekonomi dan Bisnis Universitas Udayana yang berjumlah 115 . Metode penentuan sampel yang digunakan dalam penelitian ini adalah sampling jenuh dan teknik analisis data dalam penelitian ini menggunakan analisis regresi linear berganda. Berdasarkan analisis yang dilakukan, ditemukan bahwa persepsi manfaat, persepsi kemudahan, norma subjektif dan kualitas informasi berpengaruh positif terhadap minat menggunakan $e$-commerce.
\end{abstract}

Kata Kunci: Persepsi Manfaat; Persepsi Kemudahan; Norma Subjektif; Kualitas Infromasi; E-commerce.

\section{Perceived usefulness, Perceived Ease of Use, Subjective Norms Information Quality and Interest: Study on E- commerce User}

\section{ABSTRACT}

E-commerce is a general concept in the process of buying and selling products or services through the internet network. The Technology Acceptance Model theory explains the factors that influence the behavior of users of information systems, The purpose of this study is to obtain empirical evidence of the effect of perceived usefulness, perceived ease of use, subjective norms, and quality of information on interest in using e-commerce. This research was conducted on all active college students majoring in Accounting class 2016 at the Faculty of Economics and Business, Udayana University, totaling 115 college students. The sampling method used in this study was saturated sampling and the data analysis technique in this study used multiple linear regression analysis. Based on the analysis conducted, it was found that perceived usefulness, perceived ease of use, subjective norms and quality of information had a positive effect on the interest in using e-commerce.

Keywords: Perceived Usefulness; Perceived Ease Of Use; Subjective Norms; Information Quality; E-Commerce.

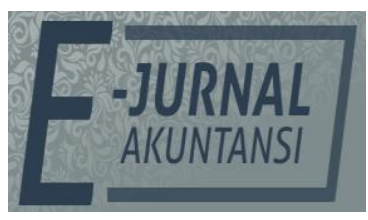

e-ISSN 2302-8556

Vol. 31 No. 5

Denpasar, Mei 2021

Hal. 1317-1330

DOI:

10.24843/EJA.2021.v31.i05.p18

PENGUTIPAN:

Aditya. I M.F., \& Putra, I M.P.D. (2021). Persepsi

Manfaat, Persepsi

Kemudahan, Norma

Subjektif, Kualitas Informasi dan Minat Penggunaan: Studi pada Pengguna $E$ commerce. E-Jurnal Akuntansi, 31(5), 1317-1330

RIWAYAT ARTIKEL: Artikel Masuk: 7 Juli 2021

Artikel Diterima: 8 Februari 2021

Artikel dapat diakses : https://ojs.unud.ac.id/index.php/Akuntansi/index 


\section{PENDAHULUAN}

Perkembangan teknologi telekomunikasi dan komputerisasi menyebabkan terjadinya perubahan budaya dalam kehidupan sehari-hari. Shomad (2012) menyatakan di era yang sudah sangat maju ini salah satunya media elektronik menjadi andalan untuk melakukan komunikasi dan bisnis. Hal ini dibuktikan dengan adanya internet yang telah menjadi suatu kebutuhan pokok atas ketersediaan informasi dan komunikasi global (Monica \& Tama, 2017).

Penggunaan internet dewasa ini sudah menjadi sebuah gaya hidup bagi sebagian penduduk di dunia, selain karena penggunaannya yang mudah, internet juga menjadi salah satu wadah perkembangan kemampuan bisnis di era digital dalam menyampaikan produk ke konsumen. Wadah tersebut merupakan salah satu solusi terbaik untuk mengurangi pengangguran tingkat sarjana yang meningkat pada tahun 2019, yaitu dengan mengembangkan jiwa kewirausahaan (Dainuri, 2019).

Badan Pusat Statistik (BPS) merilis kondisi ketenagakerjaan Indonesia tahun 2019. Data menunjukkan angka pengangguran tingkat SD, SMP, dan SMA mengalami penurunan sebesar 5,01 persen atau berkurang 50.000 orang selama satu tahun terakhir. Sedangkan jika dilihat dari tingkat pendidikan lulusan universitas masih mengalami peningkatan sebesar 25 persen. Telah banyak cara yang dilakukan untuk dapat memupuk jiwa kewirausahaan mahasiswa, yang paling utama dengan merubah mindset mereka apabila kelak setelah kuliah selesai, mereka yang selama ini berminat hanya sebagai pencari kerja (job seeker) untuk terjun ke dunia usaha (Trihudiyatmanto, 2019).

Penelitian juga mengatakan penyebaran informasi kewiraswastaan melalui internet adalah teknik utama yang mendorong anak muda untuk menciptakan bisnis berbasis internet atau e-commerce (Samašonok et al., 2016). Fenomena tentang transaksi online atau e-commerce di Indonesia merupakan suatu hal yang menarik untuk dikaji lebih lanjut. Fenomena tersebut disebabkan karena beberapa tahun terakhir ini banyak sekali masyarakat yang mulai beralih menggunakan sistem transaksi berbasis e-commerce atau belanja online dan bisnis online shop pun mempunyai prospek yang menjanjikan kedepannya.

Indonesia merupakan negara dengan pertumbuhan e-commerce tertinggi di dunia. Industri e-commerce di Indonesia dalam 10 tahun terakhir naik sekitar 17\% dan akan semakin banyak pelaku usaha, baik perusahaan besar maupun ritel beralih mengembangkan usaha ke arah digital. Diprediksikan pada tahun 2020, lebih dari separuh penduduk Indonesia terlibat dalam aktivitas e-commerce. Peralihan ke arah digital berpengaruh meningkatkan pertumbuhan ekonomi hingga US\$150 miliar dolar pada tahun 2025.

Pramiswari \& Dharmadiaksa (2017) menyatakan bahwa perkembangan teknologi informasi belakangan ini sangat membantu perjalanan usaha para wirausaha, teknologi informasi memberikan informasi secara cepat, tepat dan akurat sehingga memberikan kemudahan dalam bertransaksi. Salah satu bentuk teknologi informasi yang sedang berkembang saat ini bisnis melalui sistem elektronik seperti internet, televisi atau jaringan komputer (e-commerce) adalah pembelian, penjualan, penyebaran, pemasaran barang dan jasa.

E-commerce telah membuka sebuah peluang bagi hampir setiap orang untuk berbisnis karena dapat menciptakan bisnis pada dunia maya yang 
menghubungkan orang-orang secara luas tanpa terbatas oleh letak geografis. Konsumen dapat melakukan pemesanan barang dan atau jasa secara virtual dimanapun, 24 jam dalam satu, 7 hari, dalam 1 minggu tanpa terbatasi oleh kerja toko maupun jarak untuk mencapai toko (Pramiswari \& Dharmadiaksa, 2017). Ecommerce juga menyediakan mekanisme dalam kegiatan di dunia bisnis yaitu terdapat dua hal utama yang bisa dilakukan oleh customer yaitu melihat produk atau jasa yang diiklankan oleh perusahaan terkait melalui website dan mencari data atau informasi tertentu yang dibutuhkan sehubungan dengan proses transaksi bisnis atau dagang (jual-beli) yang akan dilakukan (Candraningrat et al., 2021).

Minat untuk berwirausaha online dapat diukur dengan menggunakan theory of planned behaviour. Teori ini didasarkan pada asumsi bahwa manusia adalah makhluk yang rasional dan menggunakan informasi-informasi yang mungkin baginya secara sistematis. Orang akan memikirkan implikasi dari tindakan mereka sebelum mereka memutuskan untuk melakukan atau tidak melakukan perilaku-perilaku tertentu.

Persepsi manfaat (perceived usefullness) didefinisikan sebagai sejauh mana seseorang percaya bahwa menggunakan suatu teknologi akan meningkatkan kinerja pekerjaannya. Monica \& Tama (2017) menyimpulkan bahwa perceived usefulness merupakan salah satu faktor yang memengaruhi minat penggunaan transaksi online. Muflihhadi \& Rubiyanti (2016) menjelaskan bahwa konstruk persepsi manfaat memengaruhi secara positif dan signifikan terhadap penggunaan sistem informasi.

Yolanda (2017) menyatakan Persepsi kemudahan penggunaan (perceived ease of use) merupakan sejauh mana seseorang yakin bahwa teknologi akan bebas dari usaha, seseorang akan lebih efisien dalam berbelanja secara online. Situs $e$ commerce termasuk mudah untuk digunakan, apalagi di era modern ini pastinya sebagian masyarakat sudah memiliki smartphone, tetapi masih ada beberapa pengguna yang merasa bahwa situs e-commerce masih rumit digunakan.

Norma subjektif (subjective norms) adalah persepsi atau pandangan seseorang terhadap kepercayaan-kepercayaan orang lain yang akan memengaruhi minat untuk melakukan atau tidak melakukan perilaku yang sedang dipertimbangkan (Sudjanarti et al., 2017). Pada konteks berwirausaha, norma subjektif berhubungan dengan pandangan seseorang terhadap tekanan sosial yang akan memengaruhi minat untuk melakukan atau tidak melakukan perilaku yang berkaitan dengan kewirausahaan. Dengan demikian pertimbangan subjektif pihak lain dapat memberikan dorongan untuk melakukan wirausaha atau keputusan berwirausaha yang kemudian lebih lanjut disebut sebagai norma subjektif.

Kualitas sistem yang terdapat pada suatu website e-commerce tentu memberikan pengaruh pada konsumen yang menggunakan e-commerce. Sharkey et al. (2010) dalam penelitiannya menyebutkan bahwa kualitas sistem memengaruhi kepuasan pengguna e-commerce. Selain kualitas sistem, kualitas informasi juga memberikan pengaruh terhadap kepuasan pengguna. Urbach (2010) menyebutkan bahwa kualitas informasi adalah faktor penting kesuksesan saat menginvestigasi kesuksesan sistem informasi secara keseluruhan, terutama dalam konteks sistem berdasarkan web. 
Minat Mahasiswa dalam menggunakan e-commerce untuk berwirausaha dapat menggunakan Teori Technology Acceptance Model (TAM) sebagai dasar dari berbagai studi sistem informasi teknologi yang dapat digunakan untuk menjawab fenomena yang terjadi (Pavlou, 2003). Davis (1989) menjelaskan bahwa TAM, merupakan teori sistem informasi yang membuat model tentang bagaimana pengguna mau menerima dan menggunakan teknologi. Model ini mengusulkan bahwa ketika pengguna ditawarkan untuk menggunakan suatu sistem yang baru, sejumlah faktor memengaruhi perilaku mereka tentang bagaimana dan kapan akan menggunakan sistem tersebut, khususnya dalam hal perceived usefulness dan perceived ease of use (Ariyanto et al., 2020).

E-commerce atau media transaksi barang atau jasa melalui sistem informasi seperti web atau media elektronik lainnya diharapkan dapat berpengaruh bagi calon wirausahawan yang ingin berwirausaha dan mempunyai modal yang relatif kecil untuk memulai membangun suatu usaha atau bisnis sehingga kemudahan dalam bertransaksi menggunakan e-commerce menjadi faktor penunjang dalam berwirausaha.

Teori TAM yang memaparkan mengenai niat untuk menggunakan sebuah teknologi baru didalamnya terdapat konstruk utama yaitu konstruk kegunaan persepsian (perceived usefulness). Davis (1989) menyatakan persepsi manfaat sebagai sajauh mana seorang percaya bahwa menggunakan suatu teknologi akan meningkatkan kinerjanya. Penelitian sebelumnya yang dilakukan oleh Davis (1989), Wibowo et al. (2015), Ahmad \& Pambudi (2014), Suwarni et al. (2015), Romadloniyah \& Prayitno (2018) menunjukan bahwa konstruk persepsi manfaat memengaruhi secara positif dan signifikan terhadap penggunaan sistem informasi. Jika seseorang merasa percaya bahwa suatu teknologi berguna maka dia akan menggunakannya, sedangkan jika menurutnya teknologi tersebut kurang berguna maka dia tidak akan menggunakannya. Berdasarkan penjelasan diatas dan hasil penelitian sebelumnya, maka hipotesis dalam penelitian ini adalah sebagai berikut.

$\mathrm{H}_{1}$ : Persepsi manfaat berpengaruh positif terhadap minat menggunakan $e$ commerce.

Konstruk kemudahan penggunaan persepsian (perceived ease of use) merupakan konstruk tambahan kedua dalam TAM, yang didefinisikan sebagai sejauh mana seseorang percaya bahwa penggunaan teknologi akan bebas dari usaha. Kemudahan penggunaan persepsian juga dikatakan sebagai kepercayaan untuk proses pengambilan keputusan. Seseorang akan menggunakan sistem teknologi informasi apabila orang tersebut mempercayai bahwa sistem teknologi informasi mudah untuk digunakan, sebaliknya apabila seseorang percaya bahwa sistem teknologi informasi tidak mudah untuk digunakan, maka orang tersebut tidak akan menggunakan sistem teknologi informasi Davis (1989). Penelitian sebelumnya yang dilakukan oleh Davis (1989), Wibowo et al. (2015), Ahmad \& Pambudi (2014), Suwarni et al. (2015), Romadloniyah \& Prayitno (2018) menunjukan bahwa konstruk persepsi kemudahan penggunaan memengaruhi secara positif dan signifikan terhadap penggunaan sistem informasi. Jika seseorang merasa percaya bahwa sistem informasi mudah digunakan, mudah dipahami, mudah dimengerti, maka ia akan menggunakannya. 
$\mathrm{H}_{2}$ : Persepsi kemudahan berpengaruh positif terhadap minat menggunakan $e^{-}$ commerce.

Theory of planned behavior (TPB) menyatakan sikap ataupun perilaku seseorang dipengaruhi oleh keyakinan bahwa perilaku tersebut akan membawa kepada hasil yang diinginkan atau tidak diinginkan. Rahmawati (2017) berpendapat bahwa norma subjektif merupakan produk dan persepsi tentang tekanan sosial dalam melaksanakan perilaku tertentu. Norma subjektif merupakan bentuk dukungan dari lingkungan sekitar. Monica \& Tama (2017), dalam penelitiannya meyatakan bahwa norma subjektif berpengaruh signifikan terhadap minat menggunakan e-commerce. Koranti (2013) menyimpulkan bahwa faktor lingkungan keluarga dan lingkungan sekitar mahasiswa terbukti berpengaruh signifikan terhadap minat berwirausaha pada mahasiswa. Penelitian lainnya terkait pengaruh norma subjektif terhadap minat menggunakan teknologi adalah penelitian (Yolanda, 2017), menyatakan bahwa norma subjektif berpengaruh positif terhadap minat menggunakan e-commerce. Kinanti \& Zaki (2013), dalam penelitiannya juga menyatakan bahwa subjective norms berpengaruh signifikan terhadap pengapdosian tiket online. Sejalan dengan pendapat tersebut, Mintardjo et al. (2016), juga menyimpulkan bahwa terdapat pengaruh yang signifikan dari norma subjektif terhadap minat beli secara online.

$\mathrm{H}_{3}$ : Norma subjektif berpengaruh positif terhadap minat menggunakan ecommerce.

Model penerimaan teknologi atau disebut TAM yang menjelaskan minat berperilaku menggunakan teknologi menjelaskan bagaimana kualitas informasi dijadikan ukuran untuk mengukur kepuasan pengguna setelah menggunakan teknologi tersebut. Kualitas sistem dan informasi merupakan kualitas ouput yang berupa informasi yang dihasilkan oleh sistem informasi yang digunakan (Mulyati et al. 2017). Amalia (2016) dan Amanusa (2015) membuktikan bahwa kualitas informasi berpengaruh positif terhadap kepuasan pengguna sistem informasi. Penelitian (Suhendro, 2016), menyatakan bahwa kualitas informasi menunjukan output dari sistem informasi yang berhubungan dengan nilai, manfaat, dan relevansi dari sistem informasi yang dihasilkan bagi pengguna sistem. Semakin tinggi kualitas informasi yang dihasilkan suatu sistem informasi, maka semakin mingkatkan kepuasan pemakai.

$\mathrm{H}_{4}$ : Kualitas informasi berpengaruh positif terhadap minat menggunakan $e$ commerce.

\section{METODE PENELITIAN}

Penelitian ini menggunakan pendekatan kuantitatif yang berbentuk penelitian asosiatif dengan tipe kausalitas. Lokasi penelitian ini dilakukan pada Fakultas Ekonomi dan Bisnis Universitas Udayana. Obyek penelitian ini adalah minat mahasiswa terhadap penggunaan e-commerce untuk berwirausaha yang dijelaskan dengan pengaruh persepsi manfaat, persepsi kemudahan, norma subjektif dan kualitas informasi yang dimiliki mahasiswa aktif jurusan akuntansi program reguler angkatan 2016.

Populasi pada penelitian ini adalah seluruh mahasiswa aktif jurusan akuntansi regular angkatan 2016 Fakultas Ekonomi dan Bisnis Universitas 
Udayana. Alasan yang mendasari dipilihnya mahasiswa jurusan akuntansi program regular angkatan 2016 karena kini berada diakhir masa perkuliahannya sehingga diharapkan telah memiliki perencanaan dalam melanjutkan karir mereka. Sampel dalam penelitian ini berjumlah 115 mahasiswa aktif. Penentuan sampel dilakukan dengan metode sampling jenuh. Metode pengumpulan data yang digunakan dalam penelitian ini adalah dengan menggunakan kuesioner, dengan cara menyebarkan kuesioner secara online dengan menggunakan aplikasi Google forms.

Teknik analisis data yang digunakan dalam penelitian ini adalah analisis regresi linear berganda. Analisis ini dilakukan dengan menggunakan program Statistical Package for Social Science (SPSS) dengan tingkat signifikansi $5 \%(\alpha=0,05)$. Persamaan analisis regresi linier berganda yaitu sebagai berikut.

$Y=\alpha+\beta 1 X 1+\beta 2 X 2+\beta 3 X 3+\beta 4 X 4+\varepsilon$.

Keterangan:

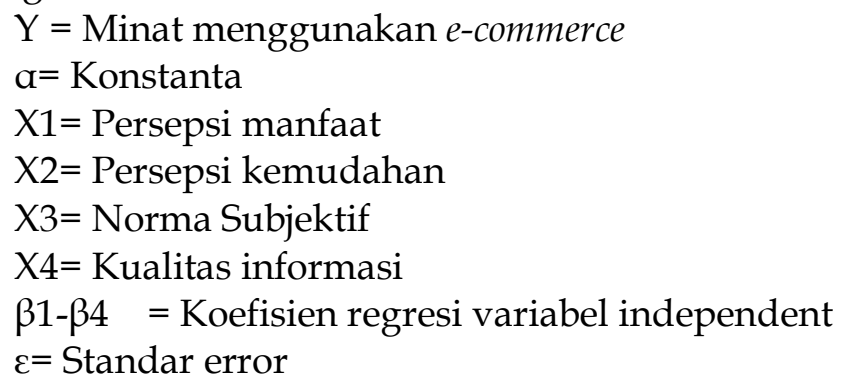

\section{HASIL DAN PEMBAHASAN}

Statistik deskriptif digunakan untuk memberikan informasi yang mendeskripsikan sifat-sifat atau karakteristik yang dimiliki oleh sampel. Statistik deskriptif dilihat dari rata-rata (mean), standar deviasi (standard deviation) dan minimum-maksimum. Hasil uji deskriptif dapat dilihat pada Tabel 1.

Tabel 1. Hasil Statistik Deskriptif

\begin{tabular}{lccccr}
\hline \multicolumn{1}{c}{ Variabel } & $\mathrm{N}$ & Nilai & & & \\
\hline Persepsi manfaat & 115 & 4 & 16 & 13,98 & 1,905 \\
Persepsi kemudahan & 115 & 6 & 16 & 13,11 & 1,927 \\
Norma subjektif & 115 & 4 & 16 & 13,20 & 2,018 \\
Kualitas informasi & 115 & 7 & 20 & 15,86 & 2,553 \\
Minat menggunakan & 115 & 5 & 20 & 16,99 & 2,396 \\
\hline
\end{tabular}

Sumber: Data Penelitian, 2020

Variabel persepsi manfaat $\left(\mathrm{X}_{1}\right)$ memiliki nilai rata-rata (mean) sebesar 13,98 Nilai rata-rata 13,98 ini artinya ada kecenderungan nilai rata-rata mendekati nilai maximum. Hal ini berarti bahwa berdasarkan jawaban atas pernyataan yang terdapat pada kuesioner variabel persepsi manfaat, mengindikasikan bahwa persepsi manfaat terhadap minat menggunakan $e$ commerce cenderung tinggi. Nilai standar deviasi perilaku belajar sebesar 1,905. Nilai ini lebih rendah dibandingkan nilai rata-rata. Hal ini menunjukkan bahwa sebaran data berupa jawaban responden pada butir-butir pernyataan persepsi manfaat dapat dinyatakan sudah merata atau rentang data satu dengan yang lainnya tidak tergolong tinggi. 
Variabel Persepsi kemudahan $\left(\mathrm{X}_{2}\right)$ memiliki nilai rata-rata (mean) sebesar 13,11. Nilai rata-rata 13,11 ini artinya ada kecenderungan nilai rata-rata mendekati nilai maksimum. Hal ini berarti bahwa berdasarkan jawaban atas pernyataan yang terdapat pada kuesioner variabel persepsi kemudahan, mengindikasikan bahwa persepsi kemudahan terhadap minat menggunakan $e$ commerce cenderung tinggi. Nilai standar deviasi persepsi kemudahan sebesar 1,927. Nilai ini lebih rendah dibandingkan nilai rata-rata. Hal ini menunjukkan bahwa sebaran data berupa jawaban responden pada butir-butir pernyataan persepsi kemudahan dapat dinyatakan sudah merata atau rentang data satu dengan yang lainnya tidak tergolong tinggi.

Variabel norma subjektif $\left(X_{3}\right)$ memiliki nilai rata-rata (mean) sebesar 13,20. Nilai rata-rata 13,20 ini artinya ada kecenderungan nilai rata-rata mendekati nilai maximum. Hal ini berarti bahwa berdasarkan jawaban atas pernyataan yang terdapat pada kuesioner variabel norma subjektif, mengindikasikan bahwa norma subjektif yang berupa dukungan keluarga maupun lingkungan luar beroengaruh terhadap minat menggugunakan e-commerce cenderung tinggi. Nilai standar deviasi norma subjektif sebesar 2,018. Nilai ini lebih rendah dibandingkan nilai rata-rata. Hal ini menunjukkan bahwa sebaran data berupa jawaban responden pada butir-butir pernyataan kecerdasan adversitas dapat dinyatakan sudah merata atau rentang data satu dengan yang lainnya tidak tergolong tinggi.

Variabel kualitas informasi $\left(\mathrm{X}_{4}\right)$ memiliki nilai rata-rata (mean) sebesar 15,86 . Nilai rata-rata 15,86 ini artinya ada kecenderungan nilai rata-rata mendekati nilai maksimum. Hal ini berarti bahwa berdasarkan jawaban atas pertanyaan yang terdapat pada kuesioner variabel kualitas informasi, mengindikasikan bahwa kualitas informasi yang dihasilkan dari e-commerce cenderung tinggi. Nilai standar deviasi kualitas informasi sebesar 2,553. Nilai ini lebih rendah dibandingkan nilai rata-rata. Hal ini menunjukkan bahwa sebaran data berupa jawaban responden pada butir-butir pertanyaan kualitas informasi dapat dinyatakan sudah merata atau rentang data satu dengan yang lainnya tidak tergolong tinggi.

Variabel minat menggunakan e-commerce $(Y)$ memiliki nilai rata-rata (mean) sebesar 16,99. Nilai rata-rata 16,99 ini artinya ada kecenderungan nilai rata-rata mendekati nilai maksimum. Hal ini berarti bahwa berdasarkan jawaban atas pertanyaan yang terdapat pada kuesioner variabel minat menggunakan $e$ commerce, mengindikasikan bahwa tingkat atau minat yang menggunakan $e$ commerce cenderung tinggi. Nilai standar deviasi tingkat minat menggunakan $e-$ commerce sebesar 2.396. Nilai ini lebih rendah dibandingkan nilai rata-rata. Hal ini menunjukkan bahwa sebaran data berupa jawaban responden pada butirbutir pertanyaan minat menggunakan e-commerce dapat dinyatakan sudah merata atau rentang data satu dengan yang lainnya tidak tergolong tinggi.

Hasil uji asumsi klasik yang mendasari model regresi pada penelitian ini, yaitu uji normalitas, uji heterokedastisitas, dan uji multikolinearitas. Hasil dari uji asumsi klasik pada penelitian ini diolah dengan bantuan software SPSS 21 for Windows masing-masing dijabarkan pada Tabel 2, 3 dan 4 berikut.

Hasil uji normalitas yang disajikkan dalam Tabel 2, menunjukkan nilai signifikansi sebesar 0,162. Karena nilai signifikansi uji Kolmogorov-Smirnov 
lebih dari 0,05 maka dapat disimpulkan bahwa model persamaan regresi tersebut berdistribusi normal.

Tabel 2. Hasil Uji Normalitas

\begin{tabular}{llr}
\hline & & Unstandardized Residual \\
\hline $\mathrm{N}$ & & 115 \\
Normal Parametersa, $b$ & Mean & 0,000 \\
& Std. & 1.537 \\
& Deviation & \\
Most Extreme Differences & Absolute & 0,074 \\
& Positive & 0,062 \\
& Negative & $-0,074$ \\
Test Statistic & & 0,074 \\
Asymp. Sig. (2-tailed) & & $0,162 \mathrm{c}$ \\
\hline
\end{tabular}

Sumber: Data Penelitian, 2020

Hasil uji multikolinearitas yang disajikkan dalam Tabel 3, dapat dilihat bahwa pada variabel persepsi manfaat nilai tolerance $0,564>0,10$ dan nilai VIF $1,772<10$. Variabel persepsi kemudahan nilai tolerance $0,426>0,10$ dan nilai VIF $2,346<10$. Variabel norma subjektif nilai tolerance $0,461>0,10$ dan nilai VIF $2,168<10$. Variabel kualitas informasi nilai tolerance $0,535>0,10$ dan nilai VIF $1,870<10$. Sehingga dapat dinyatakan bahwa keempat variabel bebas pada model regresi yang ada, tidak terjadi gejala multikolinearitas.

Tabel 3. Hasil Uji Multikolinearitas

\begin{tabular}{lccc}
\hline Variabel & Tolerance & VIF & Keterangan \\
\hline Persepsi manfaat $\left(\mathrm{X}_{1}\right)$ & 0,564 & 1,772 & Bebas multikolinearitas \\
Persepsi kemudahan $\left(\mathrm{X}_{2}\right)$ & 0,426 & 2,346 & Bebas multikolinearitas \\
Norma subjektif $\left(\mathrm{X}_{3}\right)$ & 0,461 & 2,168 & Bebas multikolinearitas \\
Kualitas informasi $\left(\mathrm{X}_{4}\right)$ & 0,535 & 1,870 & Bebas multikolinearitas \\
\hline
\end{tabular}

Sumber: Data Penelitian, 2020

Hasil uji heterokedastisitas yang disajikkan dalam Tabel 4, dapat dilihat variabel pesepsi manfaat memiliki nilai Sig. sebesar 0,838, persepsi kemudahan memiliki nilai Sig. sebesar 0,928, norma subjektif memiliki nilai Sig. sebesar 0,739. Serta variabel kualitas informasi memiliki nilai Sig. sebesar 0,079. Jika dibandingkan, nilai signifikansi masing-masing variabel bebas seluruhnya lebih besar dari 0,05. Sehingga dapat disimpulkan bahwa variabel bebas pada model regresi yang ada, tidak terjadi gejala heterokedastisitas.

Tabel 4. Hasil Uji Heterokedastisitas

\begin{tabular}{clcl}
\hline No & \multicolumn{1}{c}{ Variabel Bebas } & Signifikansi & Keterangan \\
\hline 1 & Persepsi manfaat & 0,838 & Bebas heteros \\
2 & Persepsi kemudahan & 0,928 & Bebas heteros \\
3 & Norma subjektif & 0,739 & Bebas heteros \\
4 & Kualitas informasi & 0,079 & Bebas heteros \\
\hline
\end{tabular}

Sumber: Data Penelitian, 2020

Perhitungan koefisien regresi linier berganda dilakukan dengan analisis regresi melalui software SPSS 18.0 for Windows, diperoleh hasil yang ditunjukan pada Tabel 5.

Berdasarkan hasil analisis regresi linier berganda seperti yang disajikan pada Tabel 5, maka dapat dibuat persamaan regresi sebagai berikut:

$$
Y=2,123+0,354 X_{1}+0,254 X_{2}+0,287 X_{3}+0,177 X_{4}
$$


Nilai signifikansi masing-masing variabel bebas kurang dari 0,05. Hal ini menunjukkan bahwa semua variabel bebas memiliki pengaruh yang signifikan terhadap variabel terikat.

Tabel 5. Hasil Analisis Regresi Linear Berganda

\begin{tabular}{llrrrrr}
\hline Model & \multicolumn{2}{c}{$\begin{array}{c}\text { Unstandardized } \\
\text { Coefficients }\end{array}$} & \multicolumn{2}{c}{$\begin{array}{c}\text { Standardized } \\
\text { Coefficients }\end{array}$} & & \\
\cline { 2 - 4 } & $\mathrm{B}$ & Std. Error & Beta & t & Sig. \\
\hline 1 (Constant) & 2,123 & 1,203 & & 1,764 & 0,080 \\
Persepsi manfaat & 0,354 & 0,102 & 0,281 & 3,454 & 0,001 \\
Persepsi kemudahan & 0,254 & 0,116 & 0,204 & 2,177 & 0,032 \\
Norma subjektif & 0,287 & 0,107 & 0,241 & 2,682 & 0,008 \\
Kualitas informasi & 0,177 & 0,079 & 0,189 & 2,260 & 0,026 \\
Dependen Variabel & Minat Menggunakan & & & \\
R Square & 0,589 & & & & \\
Adjusted R Square & 0,574 & & & & \\
F Statistik & 39,383 & & & & \\
Signifikansi Uji F & 0,000 & & & &
\end{tabular}

Sumber: Data Penelitian, 2020

Hasil uji koefisien determinasi dengan Adjusted $\mathrm{R}^{2}$ menunjukkan besarnya pengaruh variabel bebas terhadap variabel terikat yang ditunjukkan oleh nilai determinasi total ( $\mathrm{R}$ Square) sebesar 0,589 mempunyai arti bahwa sebesar 58,9 persen variasi Minat menggunakan dipengaruhi oleh variasi Persepsi manfaat, Persepsi kemudahan, Norma subjektif, dan Kualitas informasi, sedangkan sisanya sebesar 41,1 persen djelaskan oleh faktor lain yang tidak dimasukkan ke dalam model.

Uji kelayakan model regresi bertujuan untuk mengetahui apakah semua variabel bebas yang diidentifikasi (partisipasi anggaran, asimetri informasi, budaya organisasi, komitmen organisasi, dan sanksi perpajakan) tepat digunakan memprediksi senjangan anggaran. Uji ini sering juga disebut dengan uji F.

Hasil uji kelayakan model (Uji F) memperlihatkan nilai Fhitung sebesar 39,383 dengan nilai sig. 0,000 < 0,05, maka Ho ditolak dan $\mathrm{H}_{1}$ diterima. Kesimpulannya, pada kelompok yang diuji memiliki perbedaan yang nyata (signifikan). Hasil ini mempunyai arti bahwa ada pengaruh signifikan antara faktor Persepsi manfaat, Persepsi kemudahan, Norma subjektif, dan Kualitas informasi secara simultan terhadap minat menggunakan.

Hasil uji hipotesis pertama $\left(\mathrm{H}_{1}\right)$, menunjukkan bahwa persepsi manfaat memiliki nilai signifikansi sebesar 0,001 dengan thitung bernilai positif sebesar 3,454 . Nilai signifikansi variabel sebesar 0,001 lebih kecil dari taraf signifikansi sebesar 0,05 (5 persen) yang mengindikasikan bahwa $\mathrm{H}_{0}$ ditolak sedangkan $\mathrm{H}_{1}$ diterima. Hal ini berarti bahwa secara parsial persepsi manfaat berpengaruh pada minat menggunakan $e$-commerce.

Hasil uji hipotesis kedua $\left(\mathrm{H}_{2}\right)$, menunjukkan bahwa persepsi kemudahan memiliki nilai signifikansi sebesar 0,032 dengan thitung bernilai positif sebesar 2,177. Nilai signifikansi variabel sebesar 0,032 lebih kecil dari taraf signifikansi sebesar 0,05 (5 persen) yang mengindikasikan bahwa $\mathrm{H}_{0}$ ditolak sedang $\mathrm{H}_{1}$ diterima. Hal ini berarti bahwa secara parsial persepsi kemudahan berpengaruh positif pada minat menggunakan e-commerce. 
Hasil uji hipotesis ketiga $\left(\mathrm{H}_{3}\right)$, menunjukkan bahwa norma subjektif memiliki nilai signifikansi sebesar 0,008 dengan thitung bernilai positif sebesar 2,682. Nilai signifikansi variabel sebesar 0,008 lebih kecil dari taraf signifikansi sebesar 0,05 (5 persen) yang mengindikasikan bahwa $\mathrm{H}_{0}$ ditolak sedang $\mathrm{H}_{1}$ diterima. Hal ini berarti bahwa secara parsial norma subjektif berpengaruh positif pada minat menggunakan e-commerce.

Hasil uji hipotesis ketiga $\left(\mathrm{H}_{4}\right)$, menunjukkan bahwa kualitas informasi memiliki nilai signifikansi sebesar 0,026 dengan thitung bernilai positif sebesar 2,260. Nilai signifikansi variabel sebesar 0,026 lebih kecil dari taraf signifikansi sebesar 0,05 (5 persen) yang mengindikasikan bahwa $\mathrm{H}_{0}$ ditolak sedang $\mathrm{H}_{1}$ diterima. Hal ini berarti bahwa secara parsial kualitas informsi berpengaruh positif pada minat menggunakan e-commerce.

\section{SIMPULAN}

Berdasarkan pembahasan hasil yang diperoleh pada penelitian ini, maka dapat ditarik kesimpulan hipotesis pertama yakni Persepsi manfaat berpengaruh positif pada minat menggunakan e-commerce, yang artinya semakin tinggi persepsi manfaat yang dihasilkan suatu sistem, mempengaruhi minat menggunakan e-commerce oleh mahasiswa tersebut. Hipotesis kedua bahwa Persepsi kemudahan berpengaruh positif terhadap minat menggunakan $e$ commerce, yang artinya semakin tinggi tingkat kemudahan suatau sistem, maka akan semakin tinggi pula minat mahasiswa menggunakan e-commerce. Hipotesis ketiga bahwa Norma subjektif berpengaruh positif terhadap minat menggunakan e-commerce, yang artinya semakin tinggi persepsi mahasiswa mengenai tekanan social untuk melakukan sesuatu dalam hal ini menggunakan suatu sistem, maka akan semakin tinggi pula minat mahasiwa untuk menggunakan e-commerce. Hipotesis keemapat adalah Kualitas informasi berpengaruh positif terhadap minat menggunakan e-commerce, yang artinya semakin tinggi kualitas informasi yang dihasilkan sistem, maka dapat mendorong atau mempengaruhi perilaku untuk menggunakan sistem tersebut salah satunya minat menggunakan e-commerce.

Penelitian ini juga mengharapkan mahasiswa agar dapat meningkatkan minat dalam menggunakan e-commerce untuk berwirausaha nantinya setelah lulus perguruan tinggi. Persepsi manfaat dan persepsi kemudahan yang merupakan sejauh mana seseorang percaya bahwa menggunakan suatau teknologi akan meningkatkan kinerja. Hal ini dapat membantu mahasiswa dalam mengoptimalkan minat mereka untuk mengambil keputusan berwirausaha. Dorongan dari lingkungan yang kuat dan kualitas informasi yang dihasilkan jika menggunakan teknologi dapat membantu mahasiswa dalam decision making.

\section{REFERENSI}

Ahmad, \& Pambudi, B. S. (2014). Pengaruh Persepsi Manfaat, Persepsi Kemudahan, Keamanan Dan Ketersediaan Fitur Terhadapminat Ulang Nasabah Bank Dalam Menggunakan Internet Banking (Studi Pada Program Layanan Internet Banking Bri). Journal of Chemical Information and Modeling, 8(1), 1-11. https://doi.org/10.1017/CBO9781107415324.004 
Amalia, S. M., \& Pratomo, D. (2016). Pengaruh Kualitas Sistem Informasi, Kualitas Informasi, dan Perceived Usefulness Terhadap Kepuasan Pengguna Sistem Informasi Akuntansi ( Studi Pada Pengguna Sistem Informasi Akuntansi Di Rumah Sakit Mata Cicendo Bandung) the Influence of Information Syst. E-Proceeding of Management, 3(2), 1516-1522.

Amanusa, A. (2015). Pengaruh Kemudahan Serta Kualitas Informasi Terhadap Minat Dan Penggunaan Situs Jual Beli Online (Studi pada Pegguna Situs Jual Beli Berniaga.com). Jurnal Administrasi Bisnis S1 Universitas Brawijaya, $3(1), 1-8$.

Ariyanto, D., Dewi, A. A., \& Jhuniantara, I. M. G. (2020). Perceived learning assistance and perceived community building assistance: Study on elearning system. Systematic Reviews in Pharmacy, 11(12), 330-339. https://doi.org/10.31838/srp.2020.12.53

Candraningrat, I. R., Abundanti, N., Mujiati, N. W., Erlangga, R., \& Jhuniantara, I. M. G. (2021). The role of financial technology on development of MSMEs. Accounting, 7(1), 225-230. https://doi.org/10.5267/j.ac.2020.9.014

D. Davis, F. (1989). Perceived Usefulness, Perceived Ease of Use, and User Acceptance of Information Technology. Delle Vicende Dell'agricoltura in Italia; Studio e Note Di C. Bertagnolli., 13(3), 319-340. https://doi.org/10.5962/bhl.title.33621

Dainuri. (2019). Kontribusi Pendidikan Entrepreneurship: Suatu Upaya Konstruktif Menumbuhkan Jiwa Wirausaha Pada Mahasiswa. Journal of Sharia Economics, 1(1), 1-13.

Kinanti, F., \& Zaki, B. (2013). Analisis Determinan Sistem Informasi E-Ticketing: Pendekatan Extended Theory Of Planned Behaviour. Combustion Science and Technology, 21(5-6), 1-49.

Koranti, K. (2013). Analisis Pengaruh Faktor Eksternal dan Internal terhadap Minat Berwirausaha. Proceeding PESAT (Psikologi, Ekonomi, Sastra, Arsitektur E Teknik Sipil) Bandung, 8-9 Oktober 2013, 5, 1-8.

Mintardjo, C. M., Mandey, S., \& Binalay, A. G. (2016). Pengaruh Sikap, Norma Subjektif Dan Motivasi Terhadap Minat Beli Secara Online Pada Mahasiswa Fakultas Ekonomi Dan Bisnis Di Manado. Jurnal Riset Ekonomi, Manajemen, Bisnis Dan Akuntansi, 4(1), 395-406. https://doi.org/10.35794/emba.v4i1.11607

Monica, N., \& Tama, A. I. (2017). Pengaruh Persepsi Manfaat, Persepsi Kemudahan, Persepsi Kenyamanan, Norma Subjektif Dan Kepercayaan Terhadap Minat Menggunakan Electronic Commerce. Ekp, 8(3), 27-41.

Muflihhadi, I., \& Rubiyanti, R. N. (2016). Pengaruh Perceived Usefulness, Perceived Ease of Use, Dan Trust Terhadap Kepuasan Konsumen ( Studi Pada Gojek Bandung ) the Impact of Perceived Usefulness, Perceived Ease of Use, and Trust in Custome Rs ' Satisfaction ( Case Study in Gojek Bandung ). E-Proceeding of Management, 3(2), 2026-2033.

Mulyati, M., Aryo P, A., \& Pandora K, D. (2017). Pengaruh Kualitas Sistem Dan Informasi Pada Sistem Informasi Pembelajaran Online Terhadap Minat Pengguna Dan Penggunaan Sistem (Studi Kasus: Simponi Amik Mdp, Stmik Gi Mdp Dan Stie Mdp). Jurnal TAM ( Technology Acceptance Model ), 8(2), 90100. 
Pavlou, P. A. (2003). Consumer Acceptance of Electronic Commerce: Integrating Trust and Risk with the Technology Acceptance Model. International Journal of Electronic Commerce, 7(3), 101-134.

Pramiswari, D. A. A., \& Dharmadiaksa, I. B. (2017). Pengaruh E-commerce dan Penggunaan Sistem Informasi Akuntansi Dalam Pengambilan Keputusan Untuk Berwirausaha. E-Jurnal Akuntansi Universitas Udayana, 20(1), 261-289.

Romadloniyah, A. L., \& Prayitno, D. H. (2018). Pengaruh Persepsi Kemudahan Penggunaan, Persepsi Daya Guna, Persepsi Kepercayaan, Dan Persepsi Manfaat Terhadap Minat Nasabah Dalam Menggunaan E-Money Pada Bank Bri Lamongan. Jurnal Akuntansi, 3(2), 699-711. https://doi.org/10.30736/jpensi.v3i3.163

Samašonok, K., Išoraitė, M., \& Leškienė, B. (2016). The Internet Entrepreneurship: Opportunities And Problems. Entrepreneurship And Sustainability. Entrepreneurship And Sustainability, 0282(4), 329-349.

Sharkey, U., Scott, M., \& Acton, T. (2010). The Influence of Quality on ecommerce success: An empirical application of the delone and Mclean is success Model. International Journal of E-Business Research, 6(1), 68-84. https://doi.org/10.4018/jebr.2010100905

Shomad, A. C. (2012). Kemudahan, dan Persepsi Risiko Terhadap Perilaku Penggunaan E-Commerce Disusun Oleh: Andrie Cesario Shomad Dosen Pembimbing: Jurnal Ilmiah Mahasiswa FEB Universitas Brawijaya, 1(2), 1-20.

Sudjanarti, D., Wardani, I. T., \& Khabibah, U. (2017). Pengaruh kualitas informasi, kemampuan individu dan norma subjektif terhadap minat mahasiswa jurusan administrasi niaga polinema. Administrasi Dan Bisnis, 11(2), 190-201.

Suhendro, D. (2016). Pengaruh Kualitas Sistem, Kualitas Informasi, Kualitas Pelayanan Dan Ekspektasi Kinerja Terhadap Kepuasan Pengguna Dalam Penerapan Sistem Teknologi Informasi Pada Koperasi Di Kota Pematangsiantar. Jurasik (Jurnal Riset Sistem Informasi Dan Teknik Informatika), 1(1), 33-40. https://doi.org/10.30645/jurasik.v1i1.6

Suwarni, L., Ismail, D., Prabandari, Y. S., \& Adiyanti, M. (2015). Perceived Parental Monitoring on Adolescence Premarital Sexual Behavior in Pontianak City, Indonesia. International Journal of Public Health Science (IJPHS), 4(3), 211-219. https://doi.org/10.11591/ijphs.v4i3.4736

Trihudiyatmanto, M. (2019). Membangun Minat Berwirausaha Mahasiswa Dengan Pengaruh Faktor E-Commerce, Pengetahuan Kewirausahaan dan Gender. Jurnal Penelitian Dan Pengabdian Kepada Masyarakat UNSIQ, 6(2), 93103. https://doi.org/10.32699/ppkm.v6i2.678

Urbach, N. (2010). Structural Equation Modeling in Information Systems Research Using Partial Least Squares. Journal of Information Technology Theory and Application, 11(2), 420-432.

Wibowo, S. F., Rosmauli, D., \& Suhud, U. (2015). Pengaruh Persepsi Manfaat, Persepsi Kemudahan, Fitur Layanan, Dan Kepercayaan Terhadap Minat Menggunakan E-Money Card (Studi Pada Pengguna Jasa Commuterline Di Jakarta). JRMSI - Jurnal Riset Manajemen Sains Indonesia, 6(1), 440-456. https://doi.org/10.21009/jrmsi.006.1.06

Yolanda, A. (2017). Pengaruh Persepsi Manfaat, Persepsi Kemudahan, Persepsi 
Kenyamanan, Norma Subjektif Dan Kepercayaan Terhadap Minat Menggunakan Electronic Commerce. JRAK: Jurnal Riset Akuntansi Dan Komputerisasi Akuntansi, 8(1), 1-20. https://doi.org/10.33558/jrak.v8i1.803 